BIOMA 11 (1), 2015

Biologi UNJ Press

ISSN : 0126-3552

\title{
ISOLASI, IDENTIFIKASI DAN ENUMERASI BAKTERI Salmonella spp. PADA HASIL PERIKANAN SERTA RESISTENSINYA TERHADAP ANTIBIOTIK
}

\author{
Isolation, Identification and Enumeration of Salmonella spp. in Fishery Products and Their Resistance to \\ Antibiotics \\ RIZKY AULIA*, TRI HANDAYANI \& YUSMA YENNIE \\ ${ }^{1}$ Jurusan Biologi FMIPA Universitas Negeri Jakarta (UNJ). Jl. Pemuda No. 10 Rawamangun, Jakarta Timur. 13220. \\ Indonesia. \\ *Email: aulia.aulia27@gmail.com \\ Tanggal publikasi online:
}

\begin{abstract}
Salmonella spp. is one of the bacteria that can contaminate fresh fishery products. Diseases that can be caused by the bacteria Salmonella spp. called salmonellosis. Salmonellosis disease can be treated with antibiotics. However, the use of antibiotics continually raises the emergence strains of Salmonella bacteria that are resistant to antibiotics. This study aims to determine the prevalence and number of bacteria Salmonella spp. on fishery products as well as the resistance of Salmonella spp. to antibiotics in Jakarta and Bogor. The number of samples fresh fishery products obtained by 45 samples consisting of: a) 25 samples derived from traditional markets, and b) 20 samples derived from modern market. Isolation performed with conventional method. Identification of Salmonella spp. used biochemical and serological test. Resistance of Salmonella to antibiotics testing using disc diffusion method. The results of the identification Salmonella spp. positive sample traditional market fresh fish as much as 9 samples $(36 \%)$, whereas the modern market by 6 positive samples contaminated with Salmonella spp. $(30 \%)$. The number of bacteria Salmonella spp. from traditional market is about: 3,0×100-1,1×103 APM/g; from modern market: 3,0×100 - 2,9×102 APM/g. Based on resistance testing of Salmonella spp. to antibiotics, this bacteria has the highest level of resistance to the antibiotic erythromycin types of $93.75 \%$.
\end{abstract}

Keywords: Salmonella spp., fishery, isolation, enumeration, resistant, antibiotic, market, traditional, modern, Jakarta, Bogor.

\section{PENDAHULUAN}

Ikan dan produk perikanan merupakan bahan pangan yang mudah rusak (perishable food) karena mengandung protein dan air yang cukup tinggi. Kadar air ikan segar yang tinggi mempercepat proses perkembangbiakan mikroorganisme pembusuk yang terdapat di dalamnya. Sehingga perlakuan yang benar setelah ikan tertangkap berperan sangat penting. Perlakuan tersebut dapat 
dilakukan dengan penurunan suhu seperti pendinginan dan pembekuan untuk mencegah penurunan nilai mutu ikan serta meminimalisir keberadaan bakteri patogen (Winarni et al., 2004). Salah satu contoh bakteri yang mencemari produk perikanan ialah bakteri Salmonella. Bakteri ini merupakan salah satu bakteri patogen yang sering menginfeksi manusia melalui makanan dan minuman yang terkontaminasi (Brooks, 2005). Salmonella bertanggung jawab atas lebih dari 40.000 kasus penyakit yang berhubungan dengan makanan setiap tahun. Beberapa contoh kasus produk perikanan Indonesia terkontaminasi bakteri ini yaitu pada bulan Januari sampai April 2010 tercatat sebanyak 54\%, pada bulan Mei-Agustus 2010 tercatat 80\% dan bulan September-Desember 2010 sebanyak $61 \%$ produk perikanan di Indonesia mengandung bakteri patogen yang menyebabkan penolakan impor Indonesia ke Amerika (Food and Drug Administration, 2010 dalam Rinto, 2011).

Keberadaan bakteri Salmonella spp. pada produk perikanan menunjukan adanya kontaminasi dan kurang baiknya sistem sanitasi pada proses produksi komoditi perikanan. Menurut SNI (2009), batasan bakteri Salmonella spp. dalam makanan yaitu 0/25g sampel, yang artinya di dalam makanan tidak boleh mengandung bakteri Salmonella. Penyakit yang dapat diakibatkan oleh bakteri Salmonella disebut salmonellosis. Salmonellosis tercatat sebagai penyakit akibat pangan yang utama di dunia (CDC, 2011). Penyakit salmonellosis bersifat endemis hampir di seluruh kota besar di wilayah Indonesia, dimana kasus salmonellosis akibat Salmonella typhi mencapai 33,1 per 1000 penduduk dengan kejadian yang sama pada semua tingkat usia. Indonesia dikatagorikan sebagai salah satu negara dengan kejadian endemik salmonellosis tertinggi di Asia setelah Cina, India, dan diikuti Pakistan dan Vietnam (Ochiai, 2008).

Salah satu upaya yang dapat dilakukan untuk mengobati penyakit infeksi karena bakteri Salmonella yaitu dengan menggunakan antibiotik yang ditujukan untuk mengurangi infeksi dan mencegah terjadinya komplikasi yang serius (Sirinavin \& Garner, 2009). Upaya yang dilakukan untuk penanganan penyakit tersebut ternyata menimbulkan masalah baru, yaitu muncul strain Salmonella yang resisten terhadap antibiotik. Tingkat resistensi strain bakteri Salmonella spp. terhadap antibiotik juga telah berkembang dalam beberapa tahun terakhir, terutama terhadap antibiotik jenis aminopenicillines, tetrasiklin, sulfonamida dan kloramfenikol (Biendo et al., 2005 dalam Bouchrif et al., 2009).

Informasi mengenai keberadaan bakteri Salmonella spp. di pasar tradisional dan modern sangat terbatas, khususnya di wilayah Jakarta dan Bogor. Penelitian ini dilakukan untuk mengetahui seberapa besar prevalensi bakteri Salmonella spp. pada pasar tradisional dan modern di wilayah Jakarta dan Bogor maka pengambilan sampel di fokuskan pada wilayah tersebut. Berdasarkan penjelasan diatas, maka diharapkan penelitian ini mampu memberikan informasi yang terkait Salmonella spp. pada produk perikanan segar serta sebagai base line mengenai resistensi bakteri Salmonella spp. terhadap antibiotik.

\section{METODOLOGI PENELITIAN}

\section{Tempat dan Waktu Penelitian}

Penelitian ini dilakukan dalam laboratorium Mikrobiologi Balai Besar Penelitian dan

Pengembangan Pengolahan Produk dan Bioteknologi Kelautan dan Perikanan (BBP4BKP). 
Penelitian ini dilaksanakan pada bulan Juli-November 2014.

\section{Metode Penelitian}

Metode penelitian yang digunakan dalam penelitian ini yaitu metode deskriptif. Alat-alat yang digunakan dalam penelitian ini adalah plastik steril, stomacher, timbangan, gelas ukur, erlenmeyer, magnetic strirrer, tabung reaksi beserta rak tabung, cawan petri, mikro pipet dan tip, pinset, gunting, bunsen, ose disposable, inkubator, autoklaf, Bio Safety Cabinet (BSC), penangas air (water bath), vortex, timbangan analitik, refrigerator, spidol marker dan label.

Bahan-bahan yang digunakan dalam penelitian ini adalah sampel yang berasal dari produk perikanan segar berupa ikan, udang, kerang dan cumi-cumi yang biasa dikonsumsi oleh masyarakat, isolat murni bakteri Salmonella typhi. medium Buffer Peptone Water (BPW), medium RappaportVassiliadis Broth (RV), medium Brilliance Salmonella Agar (BSA), medium Xylose Lysine Deoxycholate agar (XLD), medium Triple Sugar Iron Agar (TSIA) slant, medium Tryptic Soy Agar (TSA), larutan garam fisiologis $(\mathrm{NaCl}) 0.85 \%$, kertas uji oxidase, rapid kit test API 20E, antisera polivalen flagellar $(\mathrm{H})$, antisera polivalen somatik $(\mathrm{O})$, dan 10 jenis antibiotik.

\section{Cara Kerja Penelitian}

\section{a. Pengambilan Sampel}

Sampel yang digunakan dalam penelitian ini adalah hasil perikanan segar (ikan, udang, kerang dan cumi) bernilai ekonomis penting yang berasal dari beberapa pasar tradisional dan modern di wilayah Jakarta dan Bogor. Lokasi pengambilan sampel di Jakarta dilakukan pada empat kotamadya yaitu Jakarta Pusat, Jakarta Timur, Jakarta Barat dan Jakarta Selatan.

Pengambilan sampel dilakukan pada waktu yang berbeda. Satu hari (pagi sampai sore) digunakan hanya untuk mengambil sampel di pasar tradisional atau pasar modern dari salah satu wilayah. Sampel yang diperoleh kemudian dimasukkan ke dalam plastik steril dan disimpan dalam cool box untuk tahap pengujian selanjutnya.

\section{b. Isolasi, Seleksi dan Identifikasi Bakteri Salmonella spp.}

\section{Tahap Pra-Pengkayaan}

Sebanyak 25 gram sampel ditimbang ke dalam botol yang berisi $225 \mathrm{ml}$ media Buffered Peptone Water (BPW). Sampel dihomogenkan dengan stomacher selama 1 menit. Kemudian di inkubasi pada suhu $35^{\circ} \mathrm{C} \pm 1{ }^{\circ} \mathrm{C}$ selama 24 jam. Adanya pertumbuhan ditandai dengan kekeruhan dan bau yang khas (Feng, 2007).

\section{Tahap Pengkayaan}

Sebanyak $0.1 \mathrm{ml}$ BPW yang telah di inkubasi dimasukkan ke dalam $10 \mathrm{ml}$ media RV. Proses inkubasi pada media $\mathrm{RV}$ dilakukan dalam waterbath yang bersuhu $42^{\circ} \mathrm{C} \pm 1^{\circ} \mathrm{C}$ selama 24 jam \pm 2 jam. (Feng, 2007).

\section{Seleksi pada Media Selektif}

Sebanyak 1 ose bakteri dari media RV diinokulasikan pada media XLD dan BSA dengan metode streak plate. Proses inkubasi dilakukan pada suhu $37^{\circ} \mathrm{C}$ selama 24 jam \pm 2 jam. Bakteri 
yang tumbuh dan diduga Salmonella spp. pada medium XLD memiliki ciri-ciri koloni berwarna merah muda dengan atau tanpa titik hitam atau terlihat hampir seluruh koloni hitam. Sedangkan pada media BSA, bakteri terduga Salmonella spp. berwarna ungu (Feng, 2007).

\section{Identifikasi Bakteri Salmonella spp.}

\section{Identifikasi Secara Biokimia}

Koloni tipikal bakteri Salmonella spp. di gores ke dalam media TSIA miring dan di inkubasi pada suhu $37^{\circ} \mathrm{C}$ selama $24 \mathrm{jam} \pm 2 \mathrm{jam}$. Perubahan pada kedua medium diamati dengan karakteristik yang tertera pada tabel 1. Proses identifikasi dilakukan dengan menggunakan kit API 20E (Feng, 2007).

Tabel 1. Karakteristik biokimia yang terbentuk dalam media TSIA

\begin{tabular}{|c|c|c|c|}
\hline \multirow{2}{*}{ No } & \multirow{2}{*}{ Karakteristik } & \multicolumn{2}{|c|}{ Bagian media } \\
\cline { 3 - 4 } & & $\begin{array}{c}\text { Lereng media } \\
\text { (slant) }\end{array}$ & Dasar Media (butt) \\
\hline 1 & Fermentasi glukosa & Merah & Kuning \\
\hline 2 & $\begin{array}{c}\text { Fermentasi sukrosa } \\
\text { dan atau laktoss }\end{array}$ & Kuning & Kuning \\
\hline 3 & Gas $\left(\mathrm{H}_{2} \mathrm{~S}\right)$ & - & Hitam \\
\hline
\end{tabular}

Keterangan: Reaksi tipikal Salmonella spp. ditunjukkan ketika media TSIA berwarna merah pada bagian lereng dan berwarna kuning pada bagian dasar media dengan atau tanpa gas $\left(\mathrm{H}_{2} \mathrm{~S}\right)$.

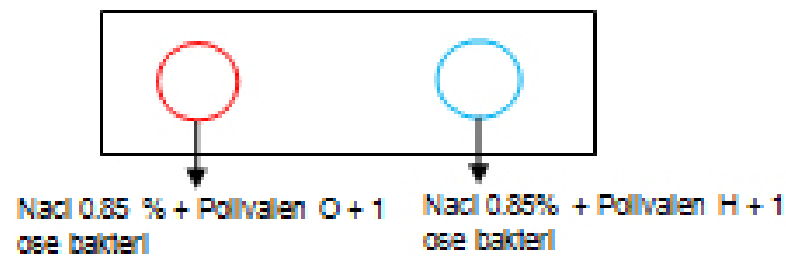

Gambar 1. Tata letak uji serologi dengan antisera polivalen $\mathbf{O}$ dan $\mathbf{H}$.

\section{Identifikasi Secara Serologi}

Identifikasi secara serologi dilakukan dengan menggunakan polivalen somatik (O) dan flagelar (H) (Feng, 2007). Hasil positif ditandai dengan adanya gumpalan (seperti pasir) berwarna putih pada suspensi. Ilustrasi uji serologi dapat dilihat pada Gambar 1.

\section{c. Enumerasi Bakteri Salmonella spp.}

Metode enumerasi atau perhitungan jumlah Salmonella spp. dalam sampel hasil perikanan dilakukan menggunakan metode Most Probable Number (MPN). Tingkat pengenceran yang digunakan pada media BPW yaitu sampai dengan 10-3 untuk sampel yang berasal dari pasar tradisional maupun modern dengan menggunakan seri 3 tabung. Kemudian dilakukan tahap uji biokimia awal dalam media TSIA dan hasil dari media tersebut dicocokkan dengan tabel MPN sebagai hasil dari enumerasi (Nillian et al., 2011; Feng, 2007).

\section{d. Uji Resistensi Salmonella spp. terhadap Antibiotik}

Pengujian resistensi antibiotik pada bakteri Salmonella spp. dilakukan berdasarkan metode 
Tabel 2. Karakteristik Diameter Standar Sensitifitas Antibiotik

(Clinical and Laboratory Standards Institute, 2012)

\begin{tabular}{|l|l|l|l|l|l|}
\multirow{2}{*}{ No } & \multirow{2}{*}{$\begin{array}{l}\text { Jenis Antibiotik } \\
\text { Cakram }\end{array}$} & & \multicolumn{3}{|c|}{ Karakteristik (mm) } \\
\cline { 6 - 6 } & & Susceptible & Intermediate & Resistant \\
\hline 1 & $\begin{array}{l}\text { Amoxicillin-clavulanic } \\
\text { acid }\end{array}$ & $20 \mu \mathrm{g}$ & $\geq 18$ & $14-17$ & $\leq 13$ \\
\hline 2 & Ciprofloxacin & $5 \mu \mathrm{g}$ & $\geq 21$ & $16-20$ & $\leq 15$ \\
\hline 3 & Gentamycin & $10 \mu \mathrm{g}$ & $\geq 15$ & $13-14$ & $\leq 12$ \\
\hline 4 & Tetracycline & $30 \mu \mathrm{g}$ & $\geq 15$ & $12-14$ & $\leq 11$ \\
\hline 5 & Chloramphenicole & $30 \mu \mathrm{g}$ & $\geq 18$ & $13-17$ & $\leq 12$ \\
\hline 6 & Streptomycin & $10 \mu \mathrm{g}$ & $\geq 15$ & $12-14$ & $\leq 11$ \\
\hline 7 & Doxycycline & $30 \mu \mathrm{g}$ & $\geq 14$ & $11-13$ & $\leq 10$ \\
\hline 8 & Nalidixic-acid & $30 \mu \mathrm{g}$ & $\geq 19$ & $14-18$ & $\leq 13$ \\
\hline 9 & Erythromycin & $15 \mu \mathrm{g}$ & $\geq 23$ & $14-22$ & $\leq 13$ \\
\hline 10 & Oxytetracycline & $30 \mu \mathrm{g}$ & $\geq 15$ & $12-14$ & $\leq 11$ \\
\hline
\end{tabular}

Tabel 3. Hasil perikanan yang diperoleh dari pasar tradisional dan modern di wilayah Jakarta dan Bogor

\begin{tabular}{|c|c|c|c|}
\hline No & Lokasi & Pasar Tradisional & Pasar Modern \\
\hline $\begin{array}{l}1 \\
2 \\
3\end{array}$ & Jakarta Pusat & $\begin{array}{l}\text { Ikan bawal } \\
\text { Ikan tenggiri }\end{array}$ & $\begin{array}{l}\text { Ikan mujair } \\
\text { Ikan tuna } \\
\text { Udang kupas }\end{array}$ \\
\hline $\begin{array}{l}4 \\
5 \\
6 \\
7 \\
8\end{array}$ & Jakarta Timur & $\begin{array}{l}\text { Kerang } \\
\text { Udang pancet } \\
\text { Udang windu } \\
\text { Ikan tongkol } \\
\text { Ikan teri segar }\end{array}$ & $\begin{array}{l}\text { Ikan bandeng } \\
\text { Udang vaname } \\
\text { Cumi-cumi }\end{array}$ \\
\hline $\begin{array}{c}9 \\
10 \\
11 \\
12\end{array}$ & Jakarta Barat & $\begin{array}{l}\text { Ikan kerapu } \\
\text { Ikan patin } \\
\text { Ikan nila } \\
\text { Ikan selar }\end{array}$ & $\begin{array}{l}\text { Ikan kerapu } \\
\text { Ikan tenggiri } \\
\text { Ikan salmon }\end{array}$ \\
\hline $\begin{array}{l}13 \\
14 \\
15 \\
16\end{array}$ & Jakarta Selatan & $\begin{array}{l}\text { Kerang } \\
\text { Cumi-cumi } \\
\text { Ikan tung } \\
\text { Ikan kembung }\end{array}$ & $\begin{array}{l}\text { Udang pancet } \\
\text { Ikan bawal } \\
\text { Ikan kembung } \\
\text { Kerang }\end{array}$ \\
\hline $\begin{array}{l}17 \\
18 \\
19 \\
20 \\
21 \\
22 \\
23 \\
24 \\
25 \\
26\end{array}$ & Bogor & $\begin{array}{l}\text { Ikan selar } \\
\text { Udang windu laut } \\
\text { Udang windu } \\
\text { Udang peci } \\
\text { Cumi-cumi } \\
\text { Ikan kuro } \\
\text { Ikan tongkol } \\
\text { Kerang } \\
\text { Ikan kembung } \\
\text { Udang api }\end{array}$ & $\begin{array}{l}\text { Ikan tenggiri } \\
\text { Udang peci } \\
\text { Udang windu } \\
\text { Udang kupas } \\
\text { Udang pancet } \\
\text { Udang vaname } \\
\text { Cumi-cumi }\end{array}$ \\
\hline Total & & 25 sampel & 20 sampel \\
\hline
\end{tabular}


standar sensitifitas yang berasal dari National Community for Clinical Laboratory Standard (NCCLS), yaitu metode cakram difusi Kirby Bauer. Media yang digunakan adalah agar MuellerHinton. Sebanyak 10 jenis antibiotik digunakan untuk menguji resistensi bakteri Salmonella spp. yaitu: amoxicillin-clavulanic acid $25 \mu \mathrm{g}$, ciprofloxacin $5 \mu \mathrm{g}$, gentamycin $10 \mu \mathrm{g}$, tetracycline $30 \mu \mathrm{g}$, chloramphenicole $30 \mu \mathrm{g}$, streptomycin $10 \mu \mathrm{g}$, doxycycline $30 \mu \mathrm{g}$, nalidixic-acid $30 \mu \mathrm{g}$, erythromycin $15 \mu \mathrm{g}$, oxytetracycline $30 \mu \mathrm{g}$.

Sebelum dilakukan uji resistensi antibiotik, bakteri Salmonella spp. dibuat suspensi menggunakan garam fisiologis $0.85 \%$ sesuai standar McFarland 0,5. Selanjutnya suspensi standar bakteri tersebut dimasukkan ke dalam cawan petri dengan metode pour plate. Proses inkubasi dilakukan selama $16-18$ jam pada suhu $35^{\circ} \mathrm{C}$ (Cavalieri et al., 2005). Terbentuknya zona bening pada media menunjukkan adanya penghambatan pertumbuhan bakteri oleh antibiotik yang diberikan. Diameter zona bening yang terlihat pada media diukur menggunakan Automatic Colony Counter tipe Scan 1200. Penentuan tingkat resistensi bakteri terhadap antibiotik dicocokkan sesuai dengan tabel diameter standar sensitifitas antibiotik (Tabel 2).

\section{HASIL DAN PEMBAHASAN}

\section{Isolasi, Identifikasi, dan Enumerasi Bakteri Salmonella spp. dari Sampel Perikanan Segar di Wilayah Jakarta dan Bogor}

Total sampel hasil perikanan segar yang di ambil dari pasar tradisional dan modern di wilayah Jakarta dan Bogor sebanyak 45 sampel dengan rincian sebagai berikut: 1) sampel pasar tradisional: 25 sampel yang terdiri atas 10 sampel berasal dari Bogor dan 15 sampel berasal dari Jakarta. 2) sampel pasar modern: 20 sampel yang terdiri dari 7 sampel berasal dari Bogor dan 13 sampel dari Jakarta.

Tabel 4. Persentase hasil isolasi sampai identifikasi pada pasar tradisional

\begin{tabular}{|c|c|l|l|l|l|}
\hline \multirow{2}{*}{ Asal Sampel } & Jumlah & \multicolumn{2}{|c|}{ Isolasi \& Seleksi } & \multicolumn{2}{c|}{ Konfirmasi } \\
\cline { 3 - 6 } & Sampel & XLD & BSA & TSIA & API 20E \\
\hline Jakarta \& Bogor & 25 & $100 \%$ & $100 \%$ & $100 \%$ & $36 \%$ \\
\hline
\end{tabular}

Sampel yang digunakan untuk uji Salmonella spp. merupakan jenis sampel yang bernilai ekonomis penting atau hasil perikanan yang umum dikonsumsi oleh masyarakat. Setiap sampel yang diperoleh sebanyak \pm 500 gr. Bagian dari sampel yang diambil untuk pengujian Salmonella

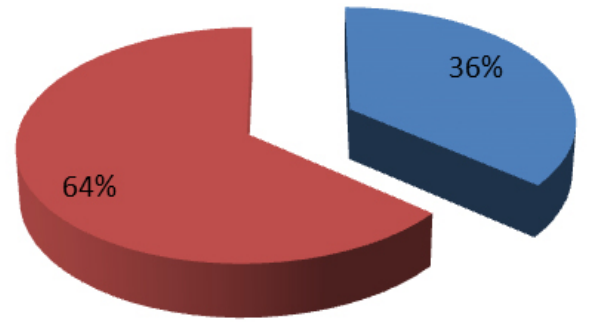

Salmonella spp. positif

- Salmonella spp. negatif

Gambar 2. Prevalensi Salmonella spp. pada pasar tradisional di wilayah Jakarta dan Bogor 
spp. yaitu bagian yang dapat dimakan (edible portion). Jenis hasil perikanan yang diperoleh dari masing-masing pasar adalah sebagai berikut (Tabel 3).

\section{Prevalensi dan Enumerasi Salmonella spp. pada Pasar Tradisional}

Tabel 4 menjelaskan bahwa hasil isolasi dan seleksi pada sampel memberikan nilai 100\%, artinya semua sampel yang diujikan tipikal bakteri Salmonella spp. namun setelah diuji lanjut secara biokimia menggunakan kit API 20E, dari 25 sampel hanya 9 sampel positif Salmonella spp. Berdasarkan perhitungan prevalensi, maka didapatkan persentase kontaminasi sebesar 36\% dari 25 sampel yang dapat dilihat pada grafik berikut (Gambar 2). Jumlah bakteri Salmonella spp. pada sampel perikanan segar dari pasar tradisonal yaitu berkisar $3,0 \times 100-1,1 \times 103 \mathrm{APM} / \mathrm{g}$.

Tabel 5. Persentase hasil isolasi sampai identifikasi pada pasar modern

\begin{tabular}{|l|l|l|l|l|l|}
\hline \multirow{2}{*}{ Asal Sampel } & Jumlah & \multicolumn{2}{|l|}{ Isolasi \& Seleksi } & \multicolumn{2}{l|}{ Konfirmasi } \\
\cline { 3 - 6 } & Sampel & XLD & BSA & TSIA & API 20E \\
\hline Jakarta \& Bogor & 20 & $100 \%$ & $100 \%$ & $100 \%$ & $30 \%$ \\
\hline
\end{tabular}

\section{Prevalensi dan Enumerasi Salmonella spp. pada Pasar Modern}

Persentase hasil isolasi sampai dengan identifikasi Salmonella spp. dapat dilihat pada tabel berikut:

Tabel 5 menjelaskan bahwa hasil isolasi dan seleksi pada sampel memberikan nilai 100\%, artinya semua sampel yang diujikan tipikal bakteri Salmonella spp. namun setelah diuji lanjut secara biokimia menggunakan kit API 20E, dari 20 sampel hanya 6 sampel positif Salmonella spp. Berdasarkan perhitungan prevalensi, maka didapatkan persentase kontaminasi sebesar 30\% dari 20 sampel yang dapat dilihat pada grafik berikut (Gambar 3). Jumlah bakteri Salmonella spp. pada sampel perikanan segar dari pasar tradisonal yaitu berkisar 3,0 × $100-2,9 \times 102 \mathrm{APM} / \mathrm{g}$.

Secara keseluruhan, sebanyak 45 sampel hasil perikanan yang diujikan menghasikan 15 sampel positif Salmonella spp. Berdasarkan perhitungan prevalensi, maka didapatkan persentase kontaminasi total sebesar 33\%, yang dapat dilihat pada grafik berikut (Gambar 4).

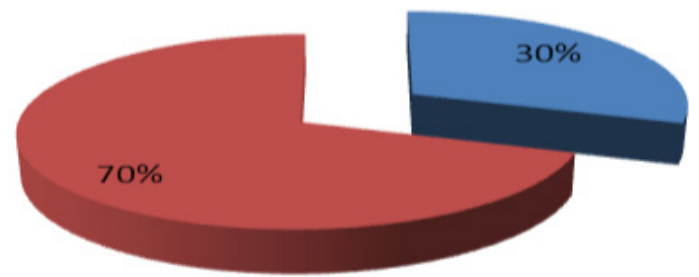

- Salmonella spp. positif

- Salmonella spp. negatif

Gambar 3. Prevalensi Salmonella spp. pada pasar modern di wilayah Jakarta dan Bogor

\section{Resistensi Bakteri Salmonella spp. terhadap Antibiotik}

Sebanyak 15 sampel positif Salmonella spp. dari sampel dan 1 isolat murni Salmonella typhi diuji resistensinya dengan 10 macam antibiotik. Diameter yang terbentuk dari setiap antibiotik pada sampel positif Salmonella spp. dan kontrol dikelompokkan sesuai dengan standar NCCLS. Berikut 
ini akan disajikan gambar hasil persentase dari hasil pengelompokan kemampuan antibiotik dalam menghambat pertumbuhan bakteri Salmonella spp. Bakteri Salmonella spp. positif dari sampel perikanan segar memiliki tingkat resistensi tertinggi terhadap antibiotik jenis erythromycin yaitu dengan nilai 93,75\% atau sebanyak 15 isolat Salmonella spp. resisten terhadap erythromycin, selanjutnya sebanyak 5 isolat Salmonella spp. juga resisten terhadap antibiotik amoxicilinclavulanic acid (31,25\%), sebanyak 2 isolat resisten terhadap tetracycline (12,50\%), 1 isolat resisten doxycycline dan nalidixic acid (6,25\%). Selain kategori resisten, berdasarkan grafik diatas dapat dilihat semua isolat positif Salmonella spp. memiliki tingkat sensitif/ kerentanan tertinggi terhadap antibiotik jenis oxytetracycline dengan nilai $100 \%$.

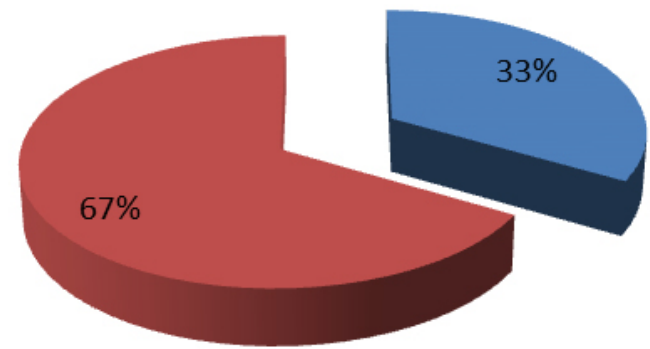

- Salmonella spp. positif

Salmonella spp. negatif

Gambar 4. Prevalensi total bakteri Salmonella spp. yang teridentifikasi dari hasil perikanan segar

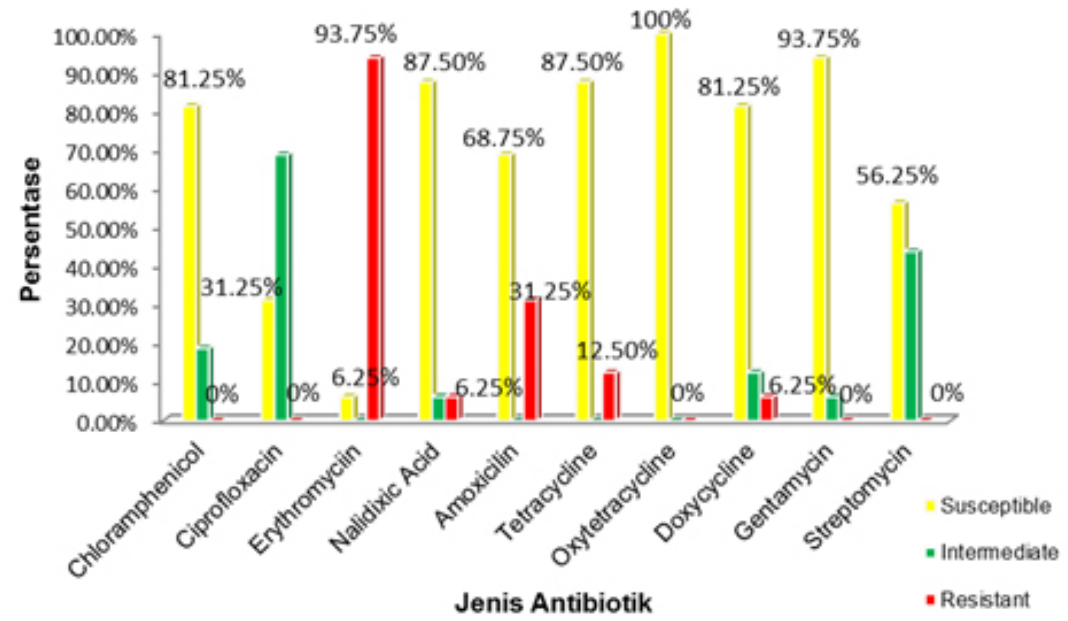

Gambar 5. Hasil Uji Resistensi 15 Isolat Salmonella spp. dari Sampel Perikanan Segar terhadap 10 Jenis Antibiotik

Tingkat kerentanan bakteri Salmonella spp. selanjutnya yaitu sebanyak 15 isolat Salmonella spp. rentan pada antibiotik jenis gentamycin (93,75\%), 14 isolat rentan terhadap nalidixic acid dan tetracycline $(87,5 \%), 13$ isolat rentan terhadap doxycycline dan chloramphenicol $(81,25 \%), 11$ isolat terhadap amoxicilin-clavulanic acid (68,75\%), 9 isolat rentan terhadap streptomycin (56,25\%) dan yang terakhir 5 isolat rentan terhadap ciprofloxacin (31,25\%). Zona hambat yang dihasilkan dari masing-masing antibiotik dapat menjadi data untuk mengelompokan sampel Salmonella spp. yang positif dengan katagori Multi Drug Resistant (MDR). Berikut ini merupakan tabel hasil jenis 
sampel Salmonella spp. positif dengan katagori MDR.

Berdasarkan tabel 6 dapat dilihat bahwa sampel positif Salmonella spp. dengan kode MCKr dan MYTi resisten pada lebih dari satu jenis antibiotik. Serovar yang dimiliki dari ke-empat sampel ini berdasarkan uji serologi yaitu: MCKr merupakan jenis Salmonella spp. dengan tipe O, dan MYTi merupakan jenis Salmonella spp. dengan tipe H.

Tabel 6. Isolat Salmonella spp. positif dari sampel perikanan dengan kategori Multi Drug Resistant

\begin{tabular}{|l|l|l|}
\hline No & Kode sampel & Jenis antibiotik \\
\hline 1 & MCKr & Tetracycline, Erythromycin, Nalidixic Acid, Amoxicilin \\
2 & MYTi & Doxycycline, Tetracycline, Erythromycin dan Amoxicilin \\
\hline
\end{tabular}

\section{PEMBAHASAN}

\section{Isolasi, Identifikasi dan Enumerasi Bakteri Salmonella spp. dari Sampel Hasil Perikanan di Wilayah Jakarta dan Bogor}

Penentuan jenis sampel dari setiap pasar didasarkan pada jenis sampel yang sering dikonsumsi oleh masyarakat. Metode isolasi bakteri Salmonella yang dilakukan menggunakan metode biakan konvensional yang mengacu pada Bacteriological Analytical Manual (BAM) dimulai dari tahap pra-pengkayaan, pengkayaan, seleksi pada media agar selektif dan yang terakhir konfirmasi secara biokimia dan serologi.
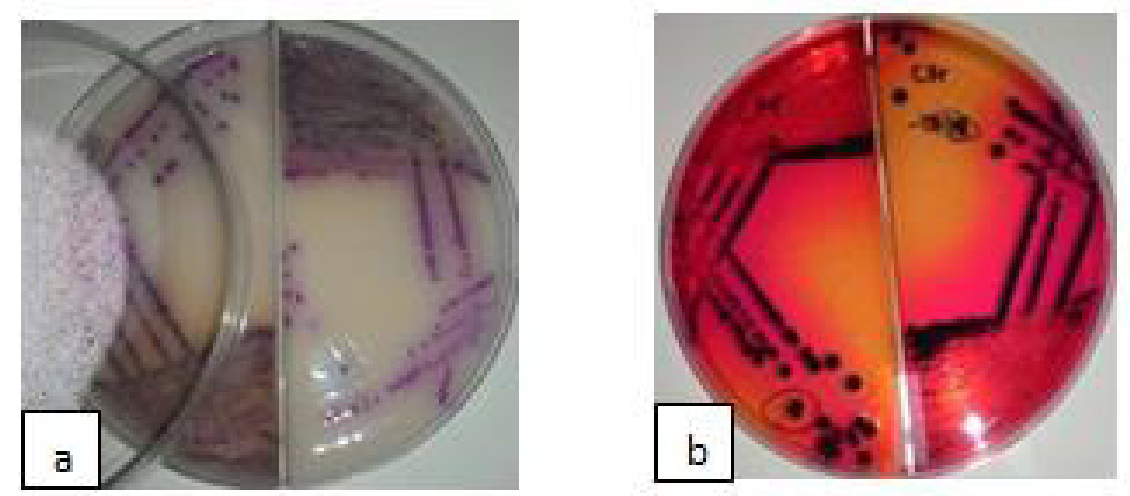

Gambar 6. Koloni tipikal Salmonella spp. yang berasal dari salah satu sampel hasil perikanan:

a) pada medium BSA dan b) pada medium XLD

Tujuan dari langkah pra-pengkayaan adalah untuk memperbanyak serta memperbaiki sel bakteri Salmonella spp. yang mungkin rusak akibat proses produksi seperti pendinginan, pemanasan dan lain-lain. Menurut Sandel et al. (2003); Gracias \& McKillip (2004) tahap pra-pengkayaan membantu dalam mengurangi tingkat kematian sel bakteri Salmonella spp. akibat pemanasan, pendinginan, pengeringan dan tekanan osmotik selama proses penanganan sampel.

Seleksi awal bakteri Salmonella spp. dilakukan dengan menggunakan dua jenis medium selektif yaitu Xylose Lysine Deoxycholate Agar (XLD) dan medium Brilliance Salmonella Agar (BSA). Kedua medium tersebut merupakan jenis media yang selektif, sehingga mampu menekan 
pertumbuhan bakteri lain yang mungkin tumbuh dalam medium. Kandungan nutrisi yang ada dalam kedua medium ini berbeda-beda namun keduanya memiliki kemampuan selektifitas yang sama sehingga dua medium ini digunakan untuk perbandingan hasil dari koloni yang tumbuh dalam medium.

Menurut Hyatt \& Weese (2004), berbagai macam media untuk pengujian bakteri Salmonella saat ini bermacam-macam, yang bertujuan untuk pebandingan koloni yang tumbuh dari masingmasing medium. Medium XLD memiliki kemampuan dalam menghambat pertumbuhan bakteri gram positif karena memiliki kandungan sodium deoxycholate, dan mengandung tiosulfat sebagai indikator $\mathrm{H} 2 \mathrm{~S}$ yang terlihat pada koloni yang tumbuh dalam media XLD. Media BSA mengandung enzim caprylate esterase yang berfungsi untuk melisiskan kromofor sehingga koloni tipikal bakteri Salmonella berwarna ungu. Berikut ini merupakan gambar dari koloni tipikal Salmonella spp. yang tumbuh dalam medium BSA dan XLD.

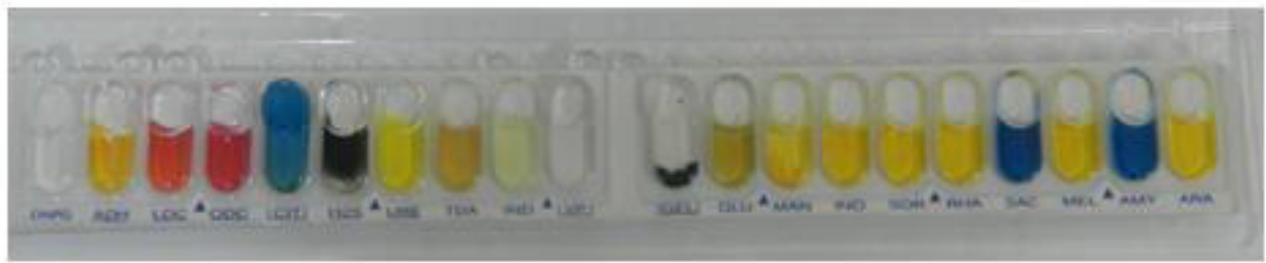

Gambar 7. Hasil positif Salmonella spp. dari sampel kerang hijau menggunakan kit API 20E.

Identifikasi bakteri Salmonella spp. dilakukan secara biokimia dan serologi. Uji biokimia awal dilakukan dengan menggunakan media Triple Sugar Iron Agar, yang kemudian dilanjutkan dengan rapid kit test API 20E. Pemilihan metode identifikasi dengan menggunakan kit API 20E karena metode ini cepat dan mudah untuk dilakukan. Selain ditemukan bakteri Salmonella, dengan menggunakan kit API 20E juga teridentifikasi lima spesies bakteri yang sering muncul pada sampel perikanan (Tabel 5). Kelima jenis bakteri ini terdiri dari 4 spesies kelompok famili Enterobacteriaceae dan 1 spesies bakteri gram negatif. Hal ini dapat terjadi karena kit API 20E merupakan kit standar yang digunakan untuk identifikasi bakteri Salmonella, bakteri dari famili Enterobacteriaceae dan bakteri gram negatif. Microtube strip API 20E memberikan hasil ketika suspensi bakteri mampu memfermentasi berbagai macam karbohidrat secara enzimatis.
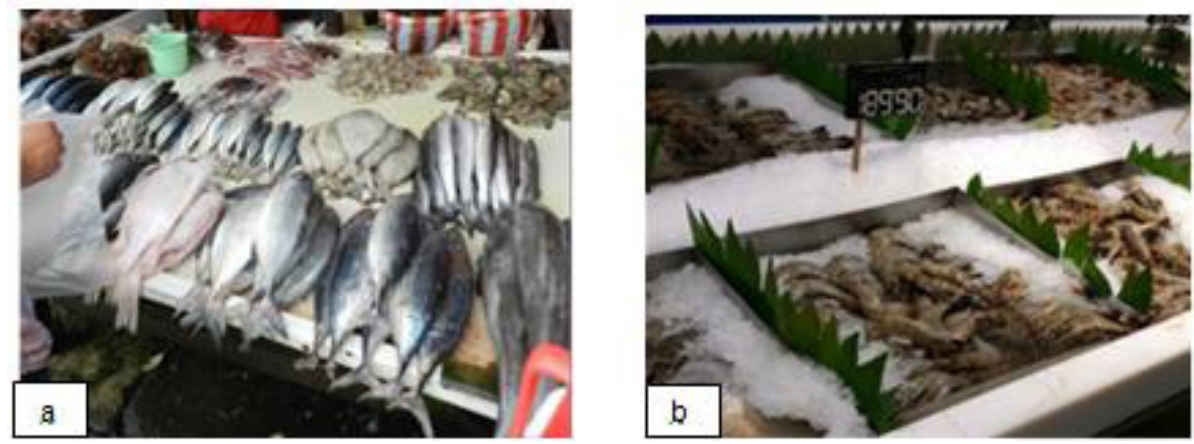

Gambar 8. Kondisi pasar : a. tradisional ; b. modern 
Identifikasi dengan menggunakan metode kit API 20E merupakan metode standar yang sering dilakukan untuk mengidentifikasi bakteri yang termasuk dalam famili Enterobacteriaceae, gram negatif, dan bakteri non-fastidious (Nucera et al., 2006). Empat bakteri (Morganella morganii, Proteus mirabilis, Enterobacter cloaceae dan Enterobacter sakazakii) merupakan jenis bakteri dari famili Enterobacteriaceae dan satu jenis bakteri yaitu Pseudomonas aeruginosa merupakan bakteri gram negatif (Baylis et al., 2011; Franzetti \& Mauro, 2007). Oleh karena itu, kelima bakteri tersebut dapat teridentifikasi pada kit API 20E karena kit API 20E bisa mengidentifikasi bakteri dari famili Enterobacteriaceae dan bakteri gram negatif. Keuntungan dari identifikasi menggunakan kit API 20E yaitu karena tidak membutuhkan waktu yang lama dan mudah untuk dilakukan, namun diperlukan biaya yang tidak sedikit untuk melakukan identifikasi dengan kit ini jika dibandingkan dengan identifikasi secara biokimia standar lainnya (Hendriksen, 2003). Gambar hasil identifikasi menggunakan kit API 20E dapat dilihat pada Gambar 7.

Gambar 7 memperlihatkan reaksi biokimia yang memberikan hasil identifikasi positif Salmonella spp. dari sampel kerang hijau menggunakan kit API 20E. Menurut Imen et al. (2012) kit API 20E mengandung substrat kering yang akan menunjukkan hasil dari aktivitas enzimatis beberapa jenis asam amino dan fermentasi karbohidrat. Hasil identifikasi diperoleh berdasarkan profil numerik yang terbagi dari 3 kategori angka yaitu 1, 2 dan 4. Angka positif yang dihasilkan kemudian dijumlahkan dan dimasukkan kedalam software API 20E. Sampel yang memberikan hasil positif Salmonella dengan probabilitas $\geq 89 \%$ dapat dikonfirmasi sebagai Salmonella spp.

Identifikasi secara serologi dilakukan untuk memperkuat hasil identifikasi secara biokimia. Polivalen $\mathrm{O}$ dan $\mathrm{H}$ digunakan untuk dapat memastikan spesies yang teridentifikasi merupakan benar Salmonella spp. berdasarkan indikasi dari penggumpalan yang terjadi pada suspensi. Menurut Oxoid (2013) karakteristik antigen merupakan salah satu karakter unggul yang dimiliki oleh bakteri Salmonella spp. Polivalen antiserum dapat digunakan sebagai tahap pertama dalam identifikasi Salmonella spp. secara menyeluruh. Hasil positif dengan penggumpalan pada kedua jenis polivalen dan atau salah satu dari mereka dapat dipastikan positif Salmonella spp. sehingga bisa memasuki tahap identifikasi lebih lanjut.

\section{Prevalensi dan Enumerasi Bakteri Salmonella spp. dari Pasar Tradisional dan Modern}

Berdasarkan hasil identifikasi, didapatkan prevalensi Salmonella spp. pada produk perikanan segar dari pasar tradisional sebesar 36\% dengan jumlah Salmonella berkisar 3,0 $\times 100-2,1 \times 103$ $\mathrm{APM} / \mathrm{g}$, sedangkan dari pasar modern sebesar 30\% dengan jumlah 3,0 × $100-2,9 \times 102 \mathrm{APM} / \mathrm{g}$. Jumlah bakteri Salmonella spp. yang diperoleh dari sampel perikanan cukup banyak dan tidak sesuai dengan kriteria SNI. Hasil tersebut juga menunjukkan prevalensi dan jumlah Salmonella spp. lebih tinggi pada pasar tradisional dibandingkan dengan pasar modern. Pasar tradisional memiliki prevalensi dan jumlah Salmonella yang lebih tinggi dibandingkan pasar modern diduga karena kondisi pada pasar tradisional kurang memiliki sanitasi yang baik sedangkan pada pasar modern memiliki sanitasi yang baik. Pasar modern memiliki tempat penjualan ikan yang bersih, serta peletakan dari masing-masing jenis ikan secara terpisah dan menggunakan es batu. Kondisi dari pasar tradisional dan modern dapat dilihat pada gambar berikut:

Menurut Aziz (2009) secara umum sanitasi dan prosedur penanganan di pasar modern lebih 
baik dan terstandar. Kontaminasi Salmonella spp. pada hasil perikanan di pasar tradisional lebih tinggi dapat disebabkan karena cara penanganan ikan pada pasar tradisional yaitu ikan diletakkan di atas alas yang terbuat dari keramik atau plastik. Keadaan yang demikian membuat air yang digunakan untuk mencuci ikan tidak terbuang sepenuhnya melainkan tergenang diatas keramik itu. Swastawati (2001) dalam Nastiti (2006) mengatakan bahwa pencucian ikan bertujuan untuk membebaskan ikan dari bakteri. Air yang dipakai untuk mencuci harus berasal dari air bersih dan bisa juga dengan air dingin. Usahakan dalam pencucian air yang digunakan mengalir sehingga air sisa pencucian membawa kotoran dan bakteri pembusuk tidak menggenang.

Rene et al. (2014) mengatakan bahwa pedagang ikan di pasar tradisional terkadang dekat dengan tempat sampah. Lalat dan hewan insekta lainnya berpindah-pindah tempat dari tempat sampah ke produk perikanan yang dijual. Hal ini menyebabkan penyebaran mikroorganisme, khususnya Salmonella.

Secara keseluruhan, prevalensi total bakteri Salmonella spp. yang dihasilkan dari sampel produk perikanan segar pada pasar tradisional dan modern sebesar 33\%. Kontaminasi tersebut mungkin terjadi karena masyarakat khususnya nelayan masih memiliki pengetahuan yang minim mengenai bahaya mikroorganisme dalam pangan sehingga dalam proses penangkapan ikan sampai dengan distribusi produk perikanan tidak sesuai dengan standar mikrobiologi. Kontaminasi silang dengan tempat penyimpanan ikan dan mutu kesegaran yang dimiliki oleh ikan juga bisa menjadi faktor kontaminasi.

Aziz (2009) menjelaskan bahwa mutu kesegaran ikan dapat mempengaruhi pertumbuhan mikroorganisme. Terdapat tiga faktor yang menyebabkan turunnya mutu ikan segar, yaitu cara penangkapan, faktor biologis, dan cara penanganan. Menurut Sanger (2010) pola dan laju penurunan mutu ikan sangat dipengaruhi oleh keadaan temperatur. Semakin tinggi suhu, semakin cepat penurunan mutu kesegaran ikan.

Menurut Popovic et al. (2010) manajemen resiko mengenai keseluruhan proses pangan harus diperhatikan mulai dari produksi sampai konsumsi. Proses pengelolaan produk perikanan harus didasarkan pada pengetahuan ilmiah secara mikrobiologi dan pemahaman mengenai proses produksi, teknologi yang digunakan untuk pengolahan, penanganan dalam memasak, penyimpanan, transportasi dan lain-lain. Kehadiran Salmonella spp. pada produk perikanan segar dianggap memiliki standar higienitas yang minim selama proses pengolahan.

Beberapa penelitian lain mengenai prevalensi bakteri Salmonella spp. pada produk perikanan juga telah dilakukan yaitu pada penelitian Iyer dan Shrivastava (1989) kontaminasi Salmonella spp. pada udang tanpa kepala 10\%, 14\% pada udang kupas, 17\% pada lobster, $14 \%$ pada cumicumi, 25\% pada ikan lele, dan 20\% dalam ikan sarden. Kumar et al. (2007) dan Robin et al. (2007) juga melaporkan bahwa di India dan Malaysia prevalensi Salmonella tertinggi terdapat pada ikan dan krustasean.

\section{Resistensi Bakteri Salmonella spp. terhadap Antibiotik}

Jenis antibiotik yang digunakan untuk uji resistensi bakteri Salmonella spp. terhadap antibiotik yaitu sebanyak sepuluh jenis, diantaranya: tetracycline, doxycycline, oxytetracycline, ciprofloxacin, 
erythromycin, chloramphenicol, amoxicillin clavulanic-acid, gentamycin, streptomycin, dan nalidixic acid. Sepuluh jenis antibiotik tersebut merupakan jenis-jenis antibiotik yang umum digunakan secara medis untuk pengobatan penyakit salmonellosis. Menurut Sirinavin \& Garner (2009) antibiotik yang memiliki daya serap yang baik terhadap sel bakteri seperti amoxycilin, chloramphenicol, tetracycline, ampicillin, golongan floroquinolone (ciprofloxacin) juga biasa digunakan untuk mengobati penyakit yang disebabkan oleh Salmonella spp.

Selain jenis antibiotik tersebut, menurut Crump et al. (2011) antibiotik yang biasa digunakan untuk pengobatan demam tifoid secara medis dan sesuai prosedur yaitu antibiotik ampicillin, trimethoprim-sulfamethoxazole, atau chloramphenicol namun, karena munculnya strain Salmonella yang resisten terhadap antibiotik tersebut, maka penggunaan antibiotik tersebut diganti dengan jenis quinolone (nalidixic acid), macrolide (erythromycin) dan third-generation cephalosporin. Kemudian menurut Maurin \& Raoult (2001); Anonim (2005) antibiotik dalam kelompok aminoglycoside (gentamycin, amikacin, dan streptomycin) juga digunakan untuk pengobatan penyakit salmonellosis.

Metode uji resistensi bakteri Salmonella spp. terhadap antibiotik dilakukan dengan menggunakan metode difusi cakram. Kelebihan dari metode ini adalah karena mudah, cepat, dan efisien karena dapat menggunakan beberapa jenis antibiotik yang dalam satu cawan petri. Resistensi atau sensitifitas dari bakteri patogen yang digunakan dalam uji antibiotik dapat diketahui dengan metode difusi cakram.

Menurut Cavalieri et al. (2005) metode difusi cakram merupakan jenis metode yang paling sering digunakan untuk pengujian sensitifitas antimikroba dibandingkan dengan dua metode pengujian lainnya. Metode ini paling banyak digunakan karena murah dan mudah dilakukan, namun memiliki kekurangan yaitu tidak dapat menentukan nilai minimum konsentrasi penghambatan (MIC).

Proses difusi bekerja ketika kertas cakram antibiotik ditempatkan diatas media Mueller Hinton Agar (MHA), dengan proses difusi dimulai dari kertas cakram ke dalam agar (Hendriksen, 2002). Kelarutan senyawa di dalam agar akan menentukan ukuran area resapan senyawa antibiotik di sekitar cakram atau yang disebut dengan zona hambat. Terbentuknya zona hambat dalam agar MHA menunjukkan bahwa senyawa antibiotik mampu menghambat pertumbuhan bakteri patogen.

Suspensi bakteri yang digunakan untuk pengujian aktivitas antibiotik disesuaikan dengan tingkat kekeruhan McFarland 0,5. Pembuatan suspensi bakteri dilakukan menggunakan garam fisiologis berkonsentrasi $0.85 \%$. Konsentrasi tersebut dibuat untuk menyeimbangkan kondisi di dalam sel bakteri. Menurut Skipor (2012), kebanyakan bakteri hidup dengan kondisi hipotonik atau kandungan air di luar sel jauh lebih tinggi dibandingkan di dalam sel. Namun demikian, jika konsentrasi garam dinaikkan maka air yang ada di dalam sel akan bergerak keluar sel, seandainya hal ini terjadi maka akan berakibat sel bakteri mengalami kekeringan yang pada akhirnya akan membunuh sel bakteri. Sehingga dengan konsentrasi garam 0,85\% bakteri akan tetap hidup.

Hasil dari uji resistensi menunjukkan bahwa isolat Salmonella spp. positif dari produk perikanan segar memiliki tingkat resisitensi tertinggi terhadap antibiotik jenis erythromycin dengan persentase sebesar 93,75\%. Sebanyak empat isolat Salmonella spp. dari sampel, selain memberikan 
hasil resisten terhadap antibiotik erythromycin juga resisten terhadap antibiotik jenis nalidixic acid, doxycycline, tetracycline dan amoxicillin clavulanic-acid, sehingga 4 isolat ini termasuk isolat yang dapat dikategorikan Multi Drug Resistant (MDR).

Bakteri gram negatif termasuk Salmonella mempunyai kemampuan multi drug effluks jika didapati senyawa antibiotik masuk ke dalam sel, selain itu bakteri gram negatif memiliki barrier pada membran luar sehingga senyawa antibiotik tidak dapat dengan mudah masuk ke dalam sel. Antibiotik erythromycin merupakan antibiotik dengan kategori spektrum hambat sempit yang hanya mampu menghambat bakteri gram positif.

Kategori Multi Drug Resistant pada bakteri di definisikan sebagai bakteri yang resisten terhadap 3 atau lebih jenis antibiotik (Magiorakos et al., 2011). Menurut Nikaido (1996); Braoudaki \& Anthony (2004) bakteri Salmonella spp. merupakan jenis bakteri gram negatif yang memiliki kemampuan multi drug effluks atau mampu memompa keluar beberapa macam jenis antibiotik lebih cepat sebelum memasuki sel. Jenis antibiotik tersebut ialah $\beta$-laktam, tetracycline, chloramphenicol, dan floroquinolone. Faktor lain yang mencegah antibiotik untuk masuk yaitu karena bakteri dari famili Enterobacteriaceae merupakan jenis bakteri yang resisten terhadap jenis penghambat lipofilik dan ampifilik. Antibiotik erythromycin merupakan jenis antibiotik lipofilik sehingga erythromycin tidak dapat masuk ke dalam sel.

Karakteristik lain dari antibiotik erythromycin yaitu erythromycin merupakan antibiotik dengan kategori antibiotik spektrum hambat yang sempit atau erythromycin hanya mampu bekerja pada mikroba gram positif(Emaliah et al., 2013). Antibiotik erythromycin tidak mampu menghambat pada bakteri gram negatif karena dinding sel bakteri gram negatif memiliki lapisan hidrofobik yang lebih tebal sehingga antibiotik erythromycin tidak dapat masuk ke dalam membran luar dan dalam dari dinding sel bakteri gram negatif (Anonim, 2007).

Hasil yang didapatkan pada penelitian ini serupa dengan hasil yang didapat dari penelitian Broughton \& Walker (2009) di Cina bahwa Salmonella hasil isolasi dari ikan memiliki tingkat resistensi pada antibotik jenis erythromycin sebesar 100\%, cotrimoxazole $(20 \%)$, gentamycin (20\%), nalidixic acid (40\%), penicillin (100\%), streptomycin (20\%), sulfanomides $(40 \%)$, tetracycline (40\%) dan trimethoprim (20\%). Berdasarkan data dari penelitian tersebut dapat dilihat bahwa antibiotik bakteri Salmonella spp. memiliki tingkat resistensi tertinggi pada antibiotik erythromycin dan bakteri ini sudah masuk dalam kategori Multi Drug Resistant.

\section{KESIMPULAN}

1. Prevalensi bakteri Salmonella spp. dari hasil perikanan pada pasar tradisional dan modern di wilayah Jakarta dan Bogor sebesar 33\% dari total 45 sampel.

2. Pasar tradisional memiliki tingkat prevalensi Salmonella spp. yang lebih tinggi dari pasar modern.

3. Bakteri Salmonella spp. memiliki tingkat resistensi tertinggi terhadap antibiotik jenis erythromycin sebesar $93,75 \%$.

4. Terdapat 2 isolat positif Salmonella spp. dari sampel perikanan segar merupakan isolat Salmonella spp. yang Multidrug Resistant (MDR) terhadap antibiotik 
jenis: amoxicillin-clavulanic acid, erythromycin, nalidixic acid, doxycycline, dan tetracycline.

\section{SARAN}

Saran untuk penelitian ini adalah perlu dilakukan tahap penelitian lebih lanjut terkait identifikasi bakteri Salmonella spp. hingga tingkat spesies dengan cara serotyping, sehingga dapat diketahui spesies Salmonella yang resisten terhadap beberapa jenis antibiotik yang digunakan.

\section{DAFTAR PUSTAKA}

Adams, M. R. dan Moss, M. O. 2008. Food microbiology Ed. 3. RSC Publishing, Cambridge: xiv $+464 \mathrm{hlm}$.

Allshouse, J., Jean, B., David, H. dan David, Z. 2004. Seafood safety and trade: 2 hlm. http://www. ers.usda.gov/media/561528/aib789-7_1_.pdf, 12 November 2014, pk 13.00 WIB.

Anonim, 2005. Salmonellosis: Paratyphoid and non-typhoidal salmonellosis: $8 \mathrm{hlm}$. http://www. cfsph.iastate.edu/Factsheets/pdfs/nontyphoidal_salmonellosis.pdf, 20 November 2014, pk. 20.30 WIB.

Anonim, 2007. Macrolide antibiotics comparison: $1 \mathrm{hlm}$. http://www.emedexpert.com/compare/ macrolides.shtml, 18 November 2014, pk 10.00 WIB.

Aziz, I. 2009. Isolasi Salmonella spp. pada tiga jenis ikan di wilayah Bogor serta uji ketahanannya terhadap pengaruh proses pengukusan. Skripsi. Jurusan Pertanian-Institut

*aulia.aulia27@gmail.com

Jurusan Biologi Fakultas Matematika dan Ilmu Pengetahuan Alam Universitas Negeri Jakarta

Pertanian Bogor: Dipublikasikan: $73 \mathrm{hlm}$.

Baylis, C., Mieke, U., Han, J. dan Andy, D. 2011. The enterobacteriaceae and their significance to the food industry. International Life Science Institute (ILSI), Europe: iii $+47 \mathrm{hlm}$.

Bell, C. dan Kyriakides, A. 2002. Salmonella a practical approach to the organism and its control in foods. Blackwell Science Ltd, UK: vi $+330 \mathrm{hlm}$.

BioMerièux. 2002. API 20E: Identification system for enterobacteriaceae and other non-fastidious gram-negative rods. BioMeriẻux Company. 07584: $5 \mathrm{hlm}$.

Bouchrif, B., Bianca, P., Manuela, M., Andrea, P., Nozha, C., Moulay, M. E., Salvatore, R. dan Mohammed, T. 2009. Prevalence and antibiotic-resistance of Salmonella isolated from food in Marocco. J. Infect Dev. Ctries. 3(1): 1-6 hlm.

Braoudaki, M. dan Anthony, C. H. 2004. Mechanisms of resistance in Salmonella enterica adapted to erythromycin, benzalkonium chloride, and triclosan. Int. J. Antimicrob. Ag. 25: 31-37 hlm.

Brooks, G. F., Butel, J. S. dan Morse, S. A. 2005. Mikrobiologi Kedokteran Ed 1. Salemba Medika, Jakarta: $369 \mathrm{hlm}$.

Broughton, E. I. dan Walker, D. G. 2009. Prevalence of antibiotic-resistant Salmonella in fish in Guangdong, China. Foodborne Pathog. Dis. 6(4): 519-521 hlm.

Cavalieri, S. J., Ronald, J. H., Yvette, S. M., Jose, O., Ivonne, D. R., Robert, L. S., Susan, E. S. dan Carol, A. S. 2005. Manual of antimicrobial susceptibility testing. American Society for 
Microbiology, USA: xiii $+228 \mathrm{hlm}$.

Centers for Disease Control and Prevention (CDC). 2011. National Salmonella surveillance overview: $12 \mathrm{hlm}$, http://www.cdc.gov/nationalsurveillance/PDFs/NationalSalmSurveill Overview_508.pdf, 5 September 2014,pk. 20.30 WIB.

Clinical and Laboratory Standards Institute (CLSI). 2012. Performance standards for antimicrobial disk susceptibility tests: Approved standard. Wayne, Pennsylvania: $76 \mathrm{hlm}$.

Cross, K. 2013. Predator-prey type mathematical model explains novel mode of interaction between Salmonella and gut bacteria: $1 \mathrm{hlm}$. http://blogs.ifr.ac.uk/ghfs/2013/04/predator-preymodel/, 2 September 2014, pk. $13.00 \mathrm{WIB}$.

Crump, J. A., Medalla, F. M., Joyce, K. W., Krueger. A. L., Hoekstra, R. M. dan Whichard, J. M. 2011. Antimicrobial resistance among invasive nontyphoidal Salmonella enterica isolates in the United States: National antimicrobial resistance monitoring system, 1996 to 2007. Antimicrob. Agents Ch. 55(3): 1148-1154 hlm.

Davies, J. dan Dorothy, D. 2010. Origins and evolution of antibiotic resistance. Microbiol. Mol. Biol. R. 74 (3): 417-433 hlm.

Elhadi, N. 2014. Prevalence and antimicrobial resistance of Salmonella spp. in raw retail froze imported freshwater fish to eastern province of Saudi Arabia. Asian Pac. J. Trop. Biomed. 4 (3): 234-238 hlm.

Emaliah., H. Y., Ovi, Y. M. dan Siti, R. P. 2013. Antibiotik. Tugas Kimia Farmasi. Jurusan FarmasiPoltekkes Kemenkes RI Pangkal Pinang. Dipublikasikan: 33hlm.

Emerson, J. C. dan French, N. 2010. Characterisation of Salmonella. Ministry of Agriculture and Forestry, Wellington: $35 \mathrm{hlm}$.

Feng, P. 2007. Bacteriological analytical manual (BAM) Salmonella: 1 hlm. http://www.fda.gov/ Food/FoodScienceResearch/LaboratoryMethods/ucm070149.htm, 28 April 2014, pk. 23.30 WIB.

Forbes, A. B., Daniel, F. S. dan Alice S. W. 2007. Bailey and scott's diagnostic microbiology Ed 12. Elsevier, China: xviii +975 hlm.

Franzetti, L. dan Mauro, S. 2007. Characterisation of Pseudomonas spp. isolated from foods. Ann. Microbiol. 57 (1): 39-47 hlm.

Giaccone, V., Paolo, C. dan Leonardo, A. 2011. Food as cause of human salmonellosis. InTech, Italy: 47-73 hlm.

Gracias, K. S. dan McKillip, J. L. 2004. A review of conventional detection and enumeration methods for pathogenic bacteria in food. Can. J. Microbiol. 50(11): 883-900 hlm.

Greenwood, D., Mike, B., Richard, S. dan Will, I. 2012. Medical Microbiology Ed. 18. Elsevier, UK: 2090 hlm.

Hatta, M. dan Ratnawati. 2008. Enteric fever in endemic areas of Indonesia: An increasing problem of resistance. J. Infect Dev. Ctries. 2(4): 279-282 hlm.

Hendriksen, R. S. 2002. Susceptibility testing of Salmonella using disk diffusion. World Health Organization, USA: $13 \mathrm{hlm}$.

Hendriksen, R. S. 2003. Kits for identification of Enterobacteriaceae Using API. World Health Organization, USA: $11 \mathrm{hlm}$. 
Himedia Laboratories. 2011. Triple sugar iron agar: 3 hlm. http://himedialabs.com/TD/M021S.pdf, 25 November 2014, pk. 21:45 WIB.

Hleba, L., M, Kačániová., Pochop, J., Lejková, J., Čuboň, J. dan Kunová, S. 2011. Antibiotic resistance of enterobacteriaceae genera and Salmonella spp., Salmonella enterica ser. Typhimurium and Enteritidis isolated from milk, cheese and other dairy products from conventional farm in Slovakia. J. Microbiol. Biotechn. 1(1): 1-20 hlm.

Hudzicki, J. 2009. Kirby-Bauer disk diffusion susceptibility test protocol: $14 \mathrm{hlm}$. http:// www.microbelibrary.org/component/resource/laboratory-test/3189-kirby-bauer-diskdiffusionsusceptibility-test-protocol, 12 Oktober 2014, pk. 10:59 WIB.

Huss, H. H. dan Gram, L. 2004. Assessment and management of seafood safety and quality. Food and Agriculture Organization of The United Nations, Rome: 1-53 hlm.

Hyatt, D. R. dan Weese, J. S. 2004. Salmonella culture: Sampling procedures and laboratory techniques. Vet. Clin. N. Am-Equine. 20(3): 57-85 hlm.

Ikawikanti, A., Masdiana, C. P. dan Dyah, A. O. 2012. Isolasi dan karakterisasi Salmonella spp. pada lingkungan peternakan ayam broiler di kota Malang. Jurnal Universitas Brawijaya. 1: 1-11 hlm.

Imen, B. S., Mzoughi, R. dan Aouni, M. 2012. Laboratory typing methods for diagnostic of Salmonella strains, the "old" organism that continued challenges. InTech, Turkey: 349$372 \mathrm{hlm}$.

Iyer, T. S. G., dan Shrivastava, K. P. 1989. On the pattern of Salmonella serotypes in fishery products, frog legs and processing environments. Fish Technology. 26: 131-137 hlm.

Kumar, S., Shabarinath, S., Khushiramani, R. dan Karunasagar, I. 2007. Detection and characterization of Salmonella associated with tropical seafood. Int. J. Food Microbiol. 114(2): 227-233 hlm.

Lawley, R., Laurie, C. dan Judy, D. 2008. The food safety hazard guidebook. RSC Publishing, UK: $433 \mathrm{hlm}$.

Lüderitz, O., Galanos, C., Risse, H. J., Ruschmann, E., Schlecht, S., Schmidt, G., SchulteHolthausen, H., Wheat, R., Westphal, O. dan Schlosshardt, J. 1966. Structural relationship of Salmonella $\mathrm{O}$ and R antigens. Annals of the New York Academy of Sciences, New York: 349-374 hlm.

Lyhs, U. 2009. Microbiological methods: Chapter 15. Blackwell Publishing, USA: 318-338 hlm.

Magiorakos, A. P., Srinivasan, A., Carey., Carmeli, Y., Falagas, M. E., Giske., Harbarth, S., Hindler, J. F., Kahlmeter, G., Olsson-Liljequist, B., Paterson, D. L., Rice, L. B., Stelling, J., Struelens, M. J., Vatopoulos, A., Weber, J. T. dan Monnet, D. L. 2011. Multidrugresistant, extensively drug-resistant and pandrug-resistant bacteria: An international expert proposal for interim standard definitions for acquired resistance. J. Clin. Microbiol. 18: 268-281 hlm.

Marbun, R. A. H. 2011. Deteksi Salmonella enterica I serotype Typhi pada bakso yang dijajakan di area kampus. Skripsi. Fakultas Kedokteran-Universitas Sumatra Utara. Dipublikasikan: $44 \mathrm{hlm}$.

Marriot, N. G. dan Gravani, R. B. 2006. Principles of food sanitation Ed. 5. Springer, United States 
of America: $413 \mathrm{hlm}$.

Maurin, M. dan Raoult, D. 2001. Use of aminoglycosides in treatment of infections due to intracellular bacteria. Antimicrob. Agents Ch. 45 (11): 2977-2986 hlm.

Nastiti, D. 2006. Kajian peningkatan mutu produk ikan manyung (Arius thalassinus) panggang di kota Semarang. Skripsi. Jurusan Sumberdaya Pangan-Universitas Diponegoro. Dipublikasikan: xi + 93 hlm.

Nikaido, H. 1996. Multidrug efflux pumps of gram-negative bacteria. J. Bacteriology. 178 (20): 5853-5899 hlm.

Nillian, E., Chai, L. C., Pui, C. F., Tunung, R., Ubong, A., Zainazor., Chilek., Son, R. dan Mitsuaki N. 2011. Simultaneous detection of

*aulia.aulia27@gmail.com

Jurusan Biologi Fakultas Matematika dan Ilmu Pengetahuan Alam Universitas Negeri Jakarta

Salmonella spp., Salmonella enteritidis and Salmonella typhimurium in raw salad vegetables and vegetarian burger patties. Food Nutr. Sc. 2: 1077-1081 hlm.

Nucera, D. M., Carol, W. M., Patricia, H. dan Ronald, M. W. 2006. Comparison of API 20E and inva PCR for identification of Salmonella enterica isolates from swine production units. J. Clin. Microbiol. 44(9): 3388-3390 hlm.

Ochiai, L. R., Camilo, J. A., M, Danovaro, C., Dong, B., Sujit, K. B., Magdarina, D. A., Zulfiqar, A. B., Do, G. C., Ali, M., Seonghye, S., John, W., Anne, L. P., Jeremy, F., Remon, A. E., Tikki, P., Claudia, M. G., Lorenz, V. S. dan John, D. C. 2008. A study of typhoid fever in five Asian countries: Disease burden and implications for controls. B. WHO. 86 (4): 260$268 \mathrm{hlm}$.

Oxoid. 2010. Dehydrated culture media: brilliance salmonella agar base (BSA): $1 \mathrm{hlm}$. http://www. oxoid.com/UK/blue/prod_detail/prod_detail.asp?pr=CM1092\&sec=\&org=124\&c=UK\& lang=EN, 25 November 2014, pk. 21:45 WIB.

Oxoid. 2011. Dehydrated culture media: xylose lysine deoxycholate agar (XLD): $1 \mathrm{hlm}$. http:// www.oxoid.com/uk/blue/prod_detail/prod_detail.asp?pr $=\mathrm{cm} 0469 \&$ org $=124 \& \mathrm{c}=$ uk\&lang =en, 23 November 2014, pk. 22:15 WIB.

Oxoid. 2013. Salmonella polyvalent agglutinating sera: $2 \mathrm{hlm}$. http://www.thermoscientific. com/content/dam/tfs/SDG/MBD/MBD\%20Documents/Instructions\%20For\%20Use/ Salmonella/Polyvalent\%20Agglutinating\%20Sera/X7800B.pdf, 30 November 2014, pk. 23:15 WIB.

Popovic, N. T., Benussi, S. A., Dzidara, P., Coz-Rakovac, R., Strunjak. P., Kozacinski, L., Jadan, M. dan Brlek-Gorski, D. 2010. Microbiological quality of marketed fresh and frozen seafood caught off the adriatic coast of Croatia. Vet.Med-Us. 55(5): 233-241 hlm.

Ray, B., Webb, N. B. dan Speck, M. L. 1976. Microbiological evaluation of blue crab processing operations. J. Food Sc. 41: 398-402 hlm.

Rene, K.A., Dadie, A., Ouastimohe., Karou, T., Dje, K. M. dan Menan, E. 2014. Serotypes and antibiotic resitance of Salmonella spp. isolated from poulty carcass and raw gizzard sold in markets and catering in Abdja,Côte D’ivoire. Int. J. Current Microbiol Appl. Sc. 3(6): 764-772 hlm. 
Rinto. 2011. Kajian penolakan ekspor produk perikanan Indonesia ke Amerika Serikat. Laporan diseminarkan pada Seminar Nasional Pengolahan Produk dan Bioteknologi Kelautan dan Perikanan III, Jakarta: $8 \mathrm{hlm}$.

Robin, T., Chai, L.C., Usha, M.R., Lee, H.Y., Fatimah, A.B., Farinazleen, M.G. dan Son, R. 2007. Characterization of Salmonella enterica isolated from street food and clinical samples in Malaysia. ASEAN Food J. 14(3): 161-173 hlm.

Sandel, M. K., Wu, Y. F., dan McKillip, J.L. 2003. Detection and recovery of sublethally-injured enterotoxigenic Staphylococcus aureus. J. Appl. Microbiol. 94(1): 90-94 hlm.

Sanger, G. 2010. Mutu kesegaran ikan tongkol (Auxis tazard) selama penyimpanan dingin. Warta WIPTEK. 35: 5 hlm.

Sirinavin, S. dan Garner, P. 2009. Antibiotics for treating Salmonella gut infections. Wiley, UK: $1-33 \mathrm{hlm}$.

Skipor, A. 2012. Sodium chloride $(\mathrm{NaCl})$ and bacteria: 1 hlm. http://www.newton.dep.anl.gov/ askasci/mole00/mole00093.htm, 4 Desember 2014, pk. 23:10 WIB.

Standar Nasional Indonesia. 2006. Cara uji mikrobiologi - Bagian 2: Penentuan Salmonella pada produk perikanan (SNI-01-2332.2). Standar Nasional Indonesia, Jakarta: $23 \mathrm{hlm}$.

Standar Nasional Indonesia. 2009. Batasan maksimum cemaran mikroba dalam pangan (SNI7388). Standar Nasional Indonesia, Jakarta: $41 \mathrm{hlm}$.

Sugumar, G. dan Mariappan, S. 2003. Survival of Salmonella sp. in freshwater and seawater microcosms under starvation. Asian Fish. Science. 16: 247-255 hlm.

World Health Organization (WHO). 2014. Antimicrobial resistance: Global report on surveillance. WHO Library Cataloguing-in-Publication Data, France: 22-256 hlm.

Winarni, T. A., Fronthea. S., Darmanto., dan Eko, N. D. 2004. Uji mutu terpadu pada beberapa spesies ikan dan produk perikanan di Indonesia. Universitas Diponegoro, Semarang: viii $+41 \mathrm{hlm}$.

Yavari, L. 2012. Antibiotic resistance in Salmonella enterica and the role of animal and animal food control. Umea University, USA: $59 \mathrm{hlm}$. 